\title{
An Investigation of First Grade Elementary Teacher Candidates' Perceptions of Their Teaching Profession Competencies: A Mixed Method Study
}

\author{
Serhat Süral ${ }^{*}$ Emel Saritaş, Gülsüm Çatalbaş \\ Department of Curriculum and Instruction, Pamukkale University, Turkey
}

Copyright $\mathrm{O} 2018$ by authors, all rights reserved. Authors agree that this article remains permanently open access under the terms of the Creative Commons Attribution License 4.0 International License

\begin{abstract}
Although teaching profession has lost its prestige over the years, the recent studies demonstrate that teaching still ranks among the top of most respected of professions. Teacher candidates' individual characteristics play a crucial role in choosing teachers and designing curriculum for educating teacher candidates. The present study is of vital importance to identify the perceptions of first grade teacher candidates enrolled in Faculty of Education towards teaching profession and whether they have teaching competencies needed or not. In this research, a mixed research, sequential explanatory mixed design was utilized in which both quantitative and qualitative data were analyzed together. The quantitative data were collected through using teaching competency scale for teacher candidates and afterwards quantitative data was statistically analyzed. It was thus attempted to draw a general picture of the research problem. According to the results obtained, an in-depth analysis of teacher candidates' perceptions of teaching competencies was required. Employing quantitative data, purposive sampling was identified and semi-structured interviews were carried out with the participants in the purposive sampling. The unidimensional scale developed by [1] and adapted into Turkish by [2] was employed for data collection in the quantitative stage of the research. When viewing teacher candidates' perceptions on their teaching competencies, first grade teacher candidates stated that they perceive themselves competent in terms of attitude and values and vocation skills.
\end{abstract}

Keywords Teacher Proficiency, Candidate Teacher, Mixed Method

\section{Introduction}

Learning by constructive construct is the process of constructing meaning by establishing a relationship between new knowledge and old knowledge and experience. The learners configure things to be learned by associating them with what they have learned in their minds. In this process, the experience, knowledge, beliefs and expectations of the learners play an important role. In this case, the learning process is the process by which the previously acquired knowledge is revealed and it is an activity that enables the students to be actively involved in the new knowledge. Learning and teaching are a universal endeavour. Both in formal education and informal education, individuals continuously exist in a learning environment. Conditions, individuals, requirements and expectations are amongst those elements which shape learning-teaching environments. Human beings are capable of learning new information every moment, every second of their lives. Learning sometimes occurs unconsciously, whereas it sometimes occurs in a planned, systematic way. On the other hand, both education and teaching are a matter of fact in which learning occurs. The concepts of education, teaching and learning are core elements of education system which intertwines and has strong ties with each other. A teacher is the major actor who performs these core elements in a planned, systematic way and coordinates them [3]

The individuals who prefer teaching as a profession should be aware of their teaching competencies and clearly share their view about what they expect from teaching profession. The current university admission system involves a process which place students to undergraduate programs according to their academic achievements. The criteria of academic success can be considered enough to identify cognitive level of the individual. However, if affective, social, psychological and many more other individual differences of teacher candidates are taken into account as a criteria for entering the education faculties, more efficient and effective teacher candidates can be part of education systems.

[4] suggests that teaching profession must be regarded as 
a profession that requires a special area of expertise and skills and those who choose teaching as a career must have certain competencies to fully perform teaching profession. In the same vein, [5] underlines that teacher must be competent and must not be limited to the person who just teaches effectively. He also points out that teaching competencies, individual characteristics, communication skills, management skills, his/her belief and attitude towards profession, instructional effectiveness of a teacher must be evaluated as a whole, so that the teacher achieves desired effects upon students.

A teacher must also control his/her cognitive world regarding how to perform the profession effectively and efficiently. The teacher thus can contribute to students by using self-discipline and self- control mechanisms effectively. "General Teacher Competencies" described by Ministry of Education in 2018 involves 3 fields of competency, namely, "vocational knowledge", "vocational skill" and "attitude and values" which are interrelated with each other and complete each other and there are 11 sub-competency fields and 65 performance indicators as well.

Table 1. Teacher Proficiency Fields

\begin{tabular}{c|c|c}
\hline $\begin{array}{c}\text { A. Vocational } \\
\text { Knowledge }\end{array}$ & B. Vocational Skill & $\begin{array}{c}\text { C. Attitude and } \\
\text { Values }\end{array}$ \\
\hline $\begin{array}{c}\text { Field } \\
\text { Knowledge }\end{array}$ & $\begin{array}{c}\text { Planning Education } \\
\text { and Instruction }\end{array}$ & $\begin{array}{c}\text { National, Moral and } \\
\text { Universal Values }\end{array}$ \\
\hline Field Training & $\begin{array}{c}\text { Creating Learning } \\
\text { Environments }\end{array}$ & Approach to Student \\
\hline $\begin{array}{c}\text { Regulation } \\
\text { Knowledge }\end{array}$ & $\begin{array}{c}\text { Managing Learning } \\
\text { and Teaching } \\
\text { Process }\end{array}$ & $\begin{array}{c}\text { Communication and } \\
\text { Cooperation }\end{array}$ \\
\hline & & $\begin{array}{c}\text { Personal and } \\
\text { Vocational } \\
\text { Development }\end{array}$ \\
\hline
\end{tabular}

[5] posits that individuals should acquire the habit of self-interrogation and put an effort to realize their self-competencies from the moment they choose teaching as a career. According to the classification made by National Ministry of Education (MEB) in 2008, teaching competencies were determined in terms of occupation, student, learning and teaching process, curriculum and family relation, in summary, all meaningful components of the educational system.

According to [6], the impact of teacher competencies on educational services is observed in national and international researches, ILO (International Labour Organization) and UNESCO carried out international researches and presented some recommendations to national governments about teaching professionals. Among these recommendations, it was underscored that the issue of educating the required number of competent teachers is as important as the issue of educating the required number of teachers.

In line with the result above, it is not easy for an individual who wants to be a teacher to what extent he/she has the required teaching competency. Therefore, teacher candidates must acquire certain awareness on their own competencies since they attended education faculties according to the results of one central examination. In particular, teacher candidates must be asked of how they see their levels in terms of designing learning and teaching environments and questioning themselves in this sense.

[7], [8] argue that "the effectiveness of a competency-based curriculum depends on covering up all developments in every sphere of a society, guiding students, motivating them to learn, active student participation and undertaking responsibility by the student. This means that no matter how a curriculum is effectively prepared, teachers should be aware of their own competencies and improve themselves to a certain degree and therefore will be able to have an efficient and qualified teacher profile.

According to [9], [10] and [11] teachers should have some certain competencies to successfully arrange and realize their learning activities which is of vital importance. In competency-based learning activities, learning environments are designed in a way that allow students to gain rich learning experiences and different types of learning activities take place. In the meantime, instruction technologies effectively use such approaches as active learning and cooperative learning. This is because organizing and realizing learning activities through a curriculum designed according to such contemporary learning approaches as competency-based and project-based learning, cooperative learning, multiple intelligence theory and constructivist learning approach are different from traditional sense of education.

When compared teaching competencies on national and international levels, there are many common aspects and these aspects can be gathered under the same roof. One of the primary aspects is that the major factor which ensures student achievement is not theoretical knowledge of a teacher but teachers' ability to organize learning and teaching process effectively. The necessity of realizing process-based instruction and evaluating the product obtained through this kind of instruction together indicates that there is a common philosophy and consensus all around the world [12].

Besides that, according to the results of quantitative survey gathered across the country as regards to The Project of Socio-Economic Development Index in Turkey supported by TUBITAK 1001 Programme in 2017, teaching profession is a highly respected and ranks among the top of most respected of professions (ranks 4th among 126 profession) which proves how the society gives credit to teaching profession. Since teachers play a significant role in educating healthy individuals, they must undoubtedly have certain competencies in terms of efficient and balanced education system. In conclusion, teacher candidates who are aware of their own competencies will have more qualified undergraduate education and will contribute them to acquire attitudes towards their profession. 
Although it is thought that teaching profession has lost its prestige, several recent studies have demonstrated that teaching profession still ranks among the top occupations. As a highly respected profession in the society, teaching profession is among the professional occupations. For this reason, individuals who will engage in teaching profession should have certain competencies. Teaching competencies are divided into two categories, namely, personal and vocational competencies. A certain part of the personal competencies are particularly may be inherent in an individual even though he /she is educated in teaching education. Students can acquire the other part of the personal competencies through education faculties. Individual characteristics of teacher candidates play a crucial role in selecting teachers and implementing curriculum to raise them.

The present study has of vital importance to identify the perceptions of first grade teacher candidates enrolled in Education Faculty towards teaching profession and whether they have teaching competencies needed or not. In this respect, the present paper aims to explore the awareness of the first grade teacher candidates in the 2017-2018 academic year on the teaching profession. In this study, answers have been sought to the following research questions:

- What are the teaching competency levels of teacher candidates?

- What are the competencies that teachers need to embrace from the teacher candidates' view?

- What are the perceptions of teacher candidates towards their teaching competencies?

\section{Method}

This section provides information on the research model, the study group and the sample size, data collection, and the validity and reliability study of data collection tools.

\subsection{Research Model}

In this research, a mixed research, sequential explanatory mixed design was utilized in which both quantitative and qualitative data were analyzed together. Sequential Explanatory Design use qualitative results to explain and interpret the findings from the quantitative phase, and quantitative findings are used to guide purposeful sampling for the qualitative phase of the research [13]. In this form of research, the priority is given to qualitative data collection and it is followed by the collection of quantitative data. In the first phase, teaching profession competencies of first grade elementary teacher candidates were determined. Aiming at in-depth explanation and analysis of quantitative results, the quantitative phase elaborately examined the perceptions of teacher candidates on their teaching profession competencies. The structure of sequential phases is presented in Figure 1.

As seen in Figure 1, the quantitative phase of the research is a descriptive study based on the relational-screening model which is one of the general screening models. The relational survey models are research models which aim to determine the presence and the level of change variance between two or more variable [14]. In the current research, quantitative data were collected through using teaching competency scale for teacher candidates and afterwards quantitative data was statistically analyzed. It was thus attempted to draw a general picture of the research problem. According to the results obtained, an in-depth analysis of teacher candidates' perceptions of teaching competencies was required. Employing quantitative data, purposive sampling was identified and semi-structured interviews were carried out with the participants in the purposive sampling. Subsequently, qualitative data were analyzed using the content analysis. In conclusion, the present paper combined qualitative and quantitative findings and in-depth explanation of quantitative data alongside statistical results were discussed.

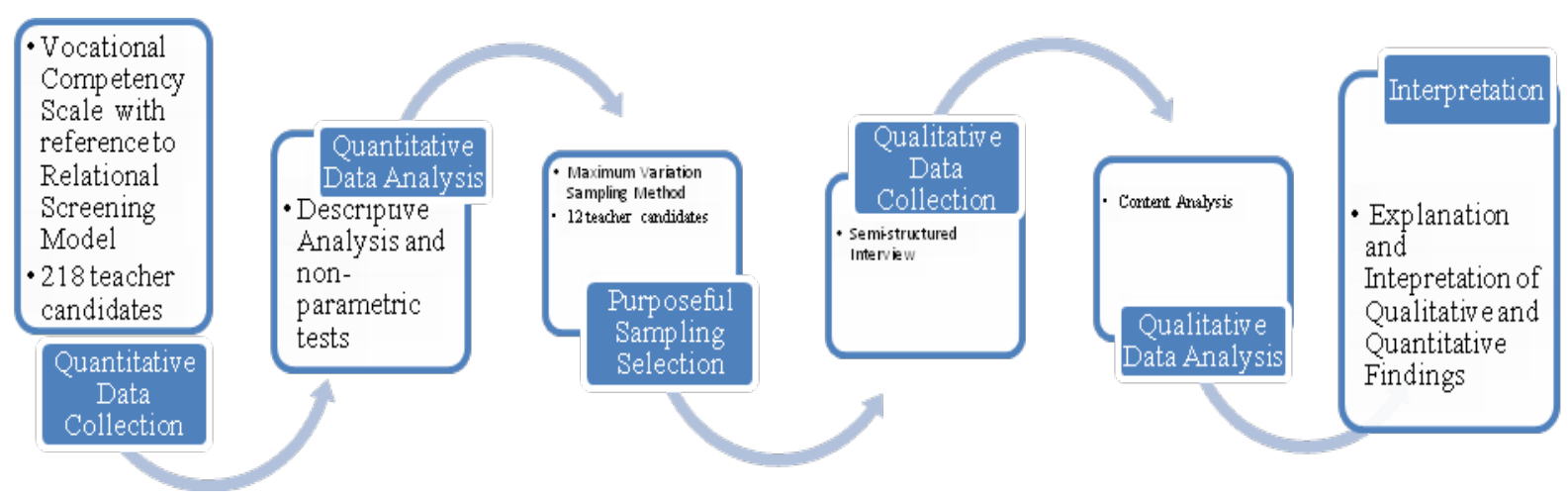

Figure 1. The running process of the descriptive sequential pattern application 


\subsection{Participants}

The participants of the quantitative phase consist of first grade students studying at Elementary Education Department of Education Faculty of Pamukkale University in the 2017-2018 academic year. Currently, 309 teacher candidates are enrolled in the Elementary Education Department. 218 of the teacher candidates were reached out. Descriptive characteristics of the study group in the quantitative phase of the study are given in Table 2.

Table 2. Frequency distribution according to the variables determined in the sampling group

\begin{tabular}{|c|c|c|c|}
\hline Variable & Group & Frequency & Percentage \\
\hline Department & $\begin{array}{c}\text { Department of classroom education } \\
\text { Department of preschool education } \\
\text { Department of preschool education (evening program) }\end{array}$ & $\begin{array}{l}80 \\
75 \\
63\end{array}$ & $\begin{array}{l}36.7 \\
34.4 \\
28.9\end{array}$ \\
\hline Gender & $\begin{array}{c}\text { Female } \\
\text { Male }\end{array}$ & $\begin{array}{l}153 \\
65\end{array}$ & $\begin{array}{l}70.2 \\
29.8\end{array}$ \\
\hline Age & $\begin{array}{c}17 \\
18 \\
19 \\
20 \text { and above }\end{array}$ & $\begin{array}{r}4 \\
90 \\
89 \\
35\end{array}$ & $\begin{array}{r}1.8 \\
41.3 \\
40.8 \\
10.6\end{array}$ \\
\hline Trainings taken & $\begin{array}{c}\text { Training course } \\
\text { Seminar } \\
\text { Certificate Programme } \\
\text { Other } \\
\text { None } \\
\text { Training Course and Seminar } \\
\text { Training Course and Certificate } \\
\text { Seminar and Certificate } \\
\text { All }\end{array}$ & $\begin{array}{l}55 \\
12 \\
11 \\
23 \\
93 \\
8 \\
5 \\
4 \\
7\end{array}$ & $\begin{array}{r}25.2 \\
5.5 \\
5.0 \\
10.6 \\
42.7 \\
3.7 \\
2.3 \\
1.8 \\
3.2\end{array}$ \\
\hline $\begin{array}{l}\text { Under the influence of } \\
\text { someone to enter the } \\
\text { teaching profession }\end{array}$ & $\begin{array}{l}\text { Yes } \\
\text { No }\end{array}$ & $\begin{array}{l}102 \\
116\end{array}$ & $\begin{array}{l}46.8 \\
53.2\end{array}$ \\
\hline $\begin{array}{c}\text { Type of high school } \\
\text { graduated }\end{array}$ & $\begin{array}{c}\text { Science high school } \\
\text { Anatolian High School } \\
\text { Anatolian Teacher High School } \\
\text { Vocational High School } \\
\text { Other }\end{array}$ & $\begin{array}{c}1 \\
138 \\
18 \\
39 \\
22\end{array}$ & $\begin{array}{c}0.5 \\
63.3 \\
8.3 \\
17.9 \\
10.1\end{array}$ \\
\hline $\begin{array}{c}\text { Type of vocational high } \\
\text { school }\end{array}$ & $\begin{array}{l}\text { Vocational medical high school } \\
\text { Religious Vocational High School } \\
\text { Vocational High School for Girls. } \\
\text { Other }\end{array}$ & $\begin{array}{c}\text { Total } \\
39 \text { people }\end{array}$ & $\begin{array}{l}20.5 \\
38.4 \\
30.7 \\
10.4\end{array}$ \\
\hline $\begin{array}{l}\text { Willingness to choose } \\
\text { teaching }\end{array}$ & $\begin{array}{l}\text { Yes } \\
\text { No }\end{array}$ & $\begin{array}{c}194 \\
24\end{array}$ & $\begin{array}{l}89.0 \\
11.0\end{array}$ \\
\hline der of preference & $\begin{array}{c}1 \text { st preference } \\
\text { 2nd preference } \\
\text { 3rd preference } \\
\text { Preference between } 4 \text { th and 10th } \\
\text { The last preference }\end{array}$ & $\begin{array}{l}48 \\
20 \\
21 \\
98 \\
31\end{array}$ & $\begin{array}{r}22.0 \\
9.2 \\
9.6 \\
45.0 \\
14.2\end{array}$ \\
\hline & TOTAL & 218 & 100 \\
\hline
\end{tabular}


As tabulated in Table 2, $36.7 \%$ of teacher candidates in the study group of the quantitative phase are enrolled in the classroom education and $63.3 \%$ of whom study preschool education. $70 \%$ of the teacher candidates are female. $63.3 \%$ of the teacher candidates are graduated from Anatolian High School. The rate of those who were willing to choose teaching profession is $89 \%$.

Basing on the qualitative results, the study group of the qualitative phase was determined according to maximum variation sampling method. The teaching competency scale scores, gender, type of high school graduated and department were taken into account and 12 teacher candidates with maximum variation were determined as the study group of the qualitative phase.

.Table 3. Descriptive characteristics of qualitative participants of the study

\begin{tabular}{|c|c|c|c|c|}
\hline & Gender & Departments & $\begin{array}{l}\text { Type of High } \\
\text { School } \\
\text { Graduated }\end{array}$ & $\begin{array}{l}\text { Scale } \\
\text { Score }\end{array}$ \\
\hline Mehmet & Male & $\begin{array}{l}\text { Classroom } \\
\text { Education }\end{array}$ & $\begin{array}{l}\text { Regular High } \\
\text { School }\end{array}$ & Low \\
\hline Metehan & Male & $\begin{array}{l}\text { Classroom } \\
\text { Education }\end{array}$ & $\begin{array}{c}\text { Anatolian } \\
\text { Teacher High } \\
\text { School }\end{array}$ & Low \\
\hline Zeynep & Female & $\begin{array}{l}\text { Preschool } \\
\text { Education }\end{array}$ & $\begin{array}{c}\text { Vocational } \\
\text { Religious } \\
\text { High School. }\end{array}$ & Low \\
\hline Havva & Female & $\begin{array}{l}\text { Classroom } \\
\text { Education }\end{array}$ & $\begin{array}{l}\text { Anatolian } \\
\text { School }\end{array}$ & $\begin{array}{l}\text { High } \\
\text { High }\end{array}$ \\
\hline Dilan & Female & $\begin{array}{l}\text { Preschool } \\
\text { Education }\end{array}$ & $\begin{array}{l}\text { Anatolian } \\
\text { School }\end{array}$ & $\begin{array}{l}\text { Low } \\
\text { High }\end{array}$ \\
\hline Mihriban & Female & $\begin{array}{l}\text { Preschool } \\
\text { Education }\end{array}$ & $\begin{array}{l}\text { Anatolian } \\
\text { School }\end{array}$ & $\begin{array}{l}\text { High } \\
\text { High }\end{array}$ \\
\hline Emre & Male & $\begin{array}{l}\text { Preschool } \\
\text { Education }\end{array}$ & $\begin{array}{c}\text { Vocational } \\
\text { Religious } \\
\text { School. }\end{array}$ & $\begin{array}{l}\text { High } \\
\text { High }\end{array}$ \\
\hline Ahmet & Male & $\begin{array}{l}\text { Preschool } \\
\text { Education }\end{array}$ & $\begin{array}{l}\text { Vocational } \\
\text { Religious } \\
\text { School. }\end{array}$ & $\begin{array}{l}\text { High } \\
\text { High }\end{array}$ \\
\hline Ramazan & Male & $\begin{array}{l}\text { Classroom } \\
\text { Education }\end{array}$ & $\begin{array}{l}\text { Anatolian } \\
\text { School }\end{array}$ & $\begin{array}{l}\text { High } \\
\text { High }\end{array}$ \\
\hline M. Ali & Male & $\begin{array}{l}\text { Classroom } \\
\text { Education }\end{array}$ & $\begin{array}{l}\text { Regular High } \\
\text { School }\end{array}$ & High \\
\hline Arzu & Female & $\begin{array}{l}\text { Classroom } \\
\text { Education }\end{array}$ & $\begin{array}{l}\text { Anatolian } \\
\text { School }\end{array}$ & $\begin{array}{l}\text { Low } \\
\text { High }\end{array}$ \\
\hline Büşra & Female & $\begin{array}{l}\text { Classroom } \\
\text { Education }\end{array}$ & $\begin{array}{l}\text { Anatolian } \\
\text { School }\end{array}$ & $\begin{array}{l}\text { High } \\
\text { High }\end{array}$ \\
\hline
\end{tabular}

Table 3 indicates 6 of the participants are enrolled in the classroom education and the remaining 6 participants are enrolled in the preschool education. The majority of the participants are graduated from Anatolian High School. As regards the scale score, the scale scores of the 5 participants are low, whereas 7 participants' scale scores are high.

\subsection{Data Collection Tools}

Teaching Competency Scale was employed for data collection in the quantitative stage of the research. The unidimensional scale was developed by [1] and adapted into Turkish by [2]. Since each item of the total 10 item-scale was consistent with the scale, factor analysis was performed on all items. Following the Principal Component Analysis, KMO value was found to be 0.76 . In order to test the reliability of the scale, the original scale was employed. Accordingly, the reliability coefficients of the scale were administrated to different sampling groups and the reliability coefficients were determined between the values of 0.74 and 0.83 . On the other hand, the reliability coefficient of the Turkish scale adapted by Sünbül and Arslan was calculated as 0.74 [2].

Students who attended pedagogical formation certificate program were selected for the sample of the study and Cronbach's Alpha reliability coefficient was calculated 0.75. In psychology, Cronbach's alpha coefficient values above 0.70 are considered acceptable for the reliability [15], [16]. Thus, the instrument is a reliable and valid scale.

In the qualitative phase of the research, semi-structured interview method was employed as data collection tool. In semi-structured interviewing, "questions to be asked are structured in advance, but the researcher allows the participant to rearrange and discuss the questions created by providing partial flexibility during the interview [17]. In the present research, the semi-structured interview form including set of open questions was developed for the participants. As emphasized by [18], clear, unambiguous, open-ended, not manipulative and multidimensional, alternative and different types of questions were formulated. The interview form was presented to two expert faculty members who were experienced in qualitative research in attempt to ensure content validity of the research and the final version of the form were given to the interview form.

Semi-structured interviews were conducted following the analysis of the quantitative results. Interviews with 12 participants in the qualitative stage lasted approximately 20 minutes for each participant. The interviews were recorded with a voice recorder upon the permission of the participant. The interviews were conducted in a friendly atmosphere and supplementary questions were asked as appropriate. The interview data were transcribed without allowing any alteration.

\subsection{Validity and Reliability of the Study}

The validity and reliability of the Teaching Competency Scale developed by [1] and adapted into Turkish by [2] were reconducted by the researchers and the reliability coefficient was found to be .767 . To ensure the reliability study and credibility (Internal Validity), semi-structured interview data were transcribed and submitted to the approval of the participants. In terms of the objectivity and ensuring the consistency, two experts teaching at classroom education and preschool education departments and specialized in qualitative research were consulted so as to prepare interview tool and evaluate and report findings. As for the confirmability (external reliability), semi-structured interview data, codes that were obtained 
from data analysis, the researcher's notes during interview were registered and when required, they are ready to use for confirmation.

\subsection{Data Analysis}

The data analysis of the research was conducted in two phases, considering the data analysis strategies followed in sequential designs as highlighted by [13]. In the first phase, quantitative data were obtained from teaching competency scale and subsequently the quantitative data were statistically analyzed. Kolmogorov- Smirnov test was administrated to the variables in the study to figure out whether variables were parametric or not. Mann-Whitney $\mathrm{U}$ and Kruskall Wallis non-parametric test were administrated to analyze the quantitative data, arithmetic mean, standard deviation as well as the significance level of teaching competencies according to the variables identified.

Qualitative data were analyzed in the second phase of the research. According to the quantitative results, the participants were selected using purposive sampling. Semi-structured interview findings obtained from the participants were analyzed according to thematic analysis. Thematic analysis involves 6 phases as follows:

1. Familiarization with the data

2. Generation of initial codes

3. Searching for themes

4. Reviewing themes

5. Defining and naming categories

6. Producing final reports [19]

\section{Findings}

To accomplish the objective of the study, quantitative data were first statistically analyzed. Following the analysis of quantitative findings, the participants were selected accordingly. The findings obtained were analyzed using semi-structured interview technique. Subsequently, qualitative and quantitative findings were interpreted together.

\subsection{Teaching Competency Levels of Teacher Candidates}

The first sub-problem of the study seeks to answer the following question: "What is the competency level of teacher candidates?". In this respect, teaching competency scale was employed to determine competency levels of teacher candidates. Accordingly, arithmetic mean and standard deviation of teacher candidates are presented in Table 4.

As the data presented in Table 4, the mean of all items in the scale results in the competency level of "Strongly Agree". Given the highest mean rank with regard to the likert-scale can be at the level of 4.00 , the highest mean were found to be 3.89 .

It is understood that the items with the highest mean score are item number 7 and $4(\bar{X}=3.89)$. Considering following elementary teacher candidates' responses regarding teaching competencies "If I try hard enough, I know that I can positively impact on my students' personal and academic developments." and "I believe, in time, I can meet the needs of my students more.", it is found that that teacher candidates have a higher level of competency perception.

Table 4. The level of participation of the sampling group in teacher competencies

\begin{tabular}{|c|c|c|c|c|c|}
\hline No & Items & $\mathrm{N}$ & $\overline{\mathrm{X}}$ & Ss & Competency Level \\
\hline I7 & $\begin{array}{l}\text { If I try hard enough, I know that I can positively impact on my } \\
\text { students' personal and academic developments. }\end{array}$ & 218 & 3.89 & 368 & Strongly Agree \\
\hline $\mathrm{I} 4$ & I believe, in time, I will meet the needs of my students more. & 218 & 3.89 & .373 & Strongly Agree \\
\hline $\mathrm{I} 3$ & I know that I can motivate my students for new projects. & 218 & 3.81 & .480 & Strongly Agree \\
\hline I8 & $\begin{array}{l}\text { I am confident that I will find appropriate ways to tackle with } \\
\text { impossibilities and administration problems and keep on teaching } \\
\text { efficiently. }\end{array}$ & 218 & 3.65 & .534 & Strongly Agree \\
\hline I9 & If I really try hard, I can reach even the most difficult students. & 218 & 3.61 & .575 & Strongly Agree \\
\hline $\mathrm{I} 2$ & $\begin{array}{l}\text { I know that I can develop good relations with parents despite some } \\
\text { tensions and issues. }\end{array}$ & 218 & 3.53 & .593 & Strongly Agree \\
\hline I5 & $\begin{array}{l}\text { I am confident that even though I am distracted during teaching, I can } \\
\text { focus again and continue teaching effectively. }\end{array}$ & 218 & 3.51 & .624 & Strongly Agree \\
\hline I1 & $\begin{array}{l}\text { I believe that I can successfully teach a course content to even the most } \\
\text { difficult student. }\end{array}$ & 218 & 3.50 & .639 & Strongly Agree \\
\hline I6 & $\begin{array}{l}\text { I believe in my ability to respond to students' needs even if I go } \\
\text { through difficult times. }\end{array}$ & 218 & 3.43 & .663 & Strongly Agree \\
\hline \multirow[t]{2}{*}{ I10 } & $\begin{array}{l}\text { I know that I can develop new projects even though my colleagues do } \\
\text { not agree with me. }\end{array}$ & 218 & 3.40 & .680 & Strongly Agree \\
\hline & Total & 218 & 3.621 & .320 & Strongly Agree \\
\hline
\end{tabular}


Besides that, according to the gathered data, it seems that the item with the lowest mean regarding teaching competency is following item number 10 "I know that I can develop new projects even though my colleagues do not agree with me." The mean score of the mentioned item was calculated $(\bar{X}=3.40)$.

Basing on the data given in Table 3, the mean of the items is distributed between 3.40 and 3.89 , indicating a narrow range. We thus can imply that the views of teacher candidates on teaching competencies are similar to each other. To understand it more clearly, the graphic is illustrated in Figure 2.

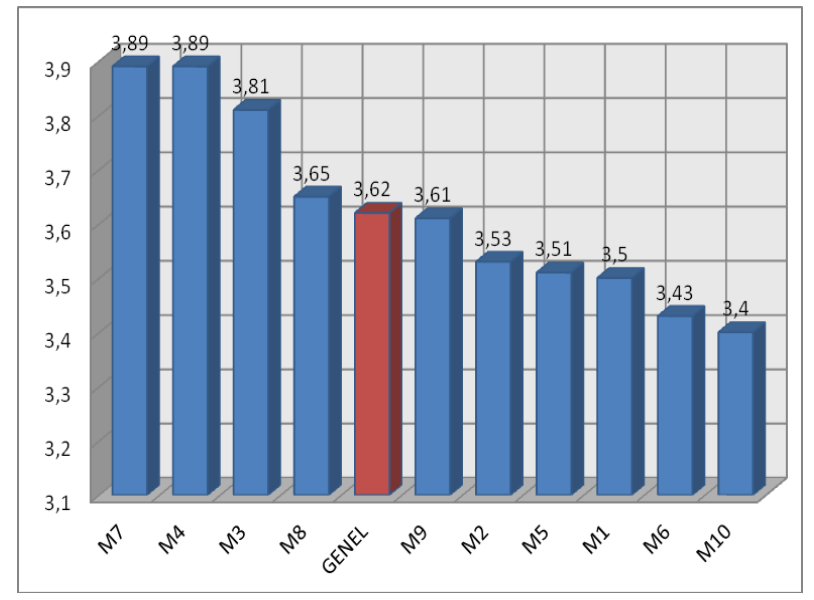

Figure 2. Teacher proficiency levels of teacher candidates in the study

Figure 2 shows that the mean levels of each items are almost equal to each other as mentioned above; 6 items ranked lower mean level than the grand mean rank $(\bar{X}=$ $3,62)$. In the qualitative phase of the research, semi-structured interview was carried out to figure out how participants see the concept of teaching competency and perceive themselves in this respect. As a result, two main themes were identified, namely, the perception of teaching competency and the perceptions of teacher candidates on their teaching competencies. The sub-themes were identified as seen in Figure 3 below.

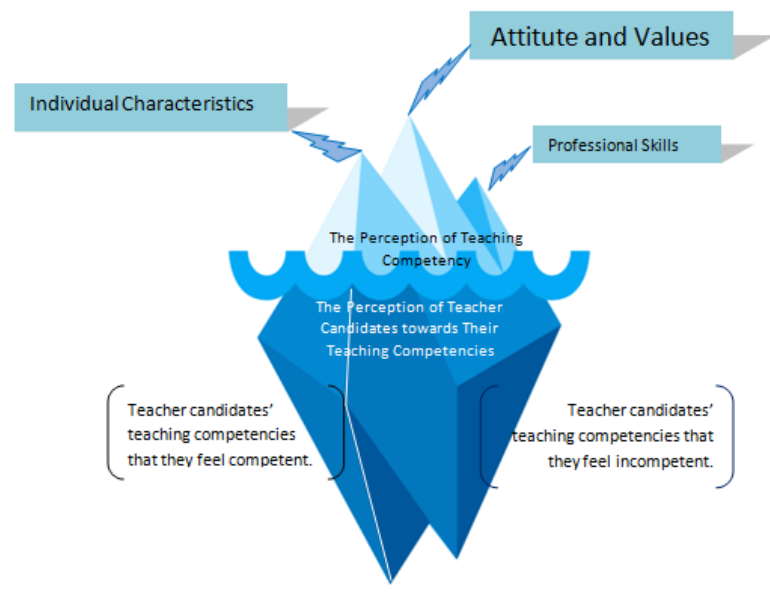

Figure 3. The main themes and sub-themes according to qualitative data (iceberg model)

\subsection{The Perception of Teaching Competence}

Participants of the semi-structured interview were asked "What are the competencies that teachers need to embrace?". Since teacher candidates do not have a prior knowledge about the concept of competency, they mostly shared their previous experiences with their teachers throughout their education life. Considering the views of teacher candidates, teacher candidates' perception of teaching competency were discussed according to the following themes identified: individual characteristics, attitude and values and vocational skills.

The findings regarding "Individual characteristics" theme indicate that participants mainly associate the concept of teaching competency with teachers' individual characteristics. With reference to the definition of the concept of teaching competency, the participants describe teachers as "patient, compassionate, self-sacrificing, kindly but firmly or authoritative". It is inferred that teacher candidates misconceptualize the concept of competency. By expressing teachers' individual characteristics, the participants remarked that teachers had a significant influence on students' learning process.

"Being Patient" is the most stressed individual characteristics by the participants. Stating that a teacher must be patient, Metehan argues teachers may have slow learners in the class and they should be very patient with their students and explains his views as follows: "I mean patience...some will understand when you have been teaching for ten minutes, some will understand within twenty minutes. But they can understand in a different way in five minutes". On the other hand, Mehmet defines being patient as a competency and assumes it as the most significant individual characteristic of a teacher. $\mathrm{He}$ associates being patient with his experience with one of his teachers. Stating that one of his teachers at the secondary school was patient with him, he explains being patient as follow: "teacher can unrelentingly convey the information to my students, students... I mean you know without scolding".

According to opinions of teacher candidates, being compassionate and self-sacrificing are amongst the individual characteristics that a teacher need to embrace and they define these characteristics as teaching competencies Describing being compassionate as the most crucial personal traits, Dilan recalls one of her negative experiences with her primary school teacher and says "Teacher should be compassionate first. (When asked to be a bit clearer, she tells her memory with her primary school teachers.)...I don't know how to say. I still remember the day when he smacked my head against the desk. I mean I was badly affected. That's why I'm against the violence. Because I experienced it before." Zeynep discusses being patient and compassionate together and says as follows "Teaching means being patient and self-sacrificing".

Under the individual characteristics theme, "Being Authoritative" is referred as another individual 
characteristic. Havva is one of the teacher candidates who shares her views on being authoritative which she considers it as a teaching competency. Havva describes students as silly putty and teacher as the one who shapes silly putty. She thinks that teacher must be authoritative whilst fulfilling her/his role. Describing herself as a tough person, Havva shares following views on being authoritative:

"I believe that teacher must be authoritative. Because if a teacher is tough, that child...yes maybe children can be influenced in a way that.. Maybe they can be scared. They can be educated like under pressure. As a characteristic.. I mean suppressed students...They fear but if the teacher uses authority, children become attached to you. If they attach to you, they obey your words. And after a while, they begin to see their teacher as role model. So, you need to be role model first".

The present study also discusses attitudes and values, and vocational skills sub-themes under the main theme of the perception of teaching competency. These sub-themes were generated in view of teacher candidates' opinions on teaching competencies.

The theme of attitudes and values were determined according to the participants' statements. In this respect, the participants highlighted following competencies: teacher's attitude towards a student, personal and vocational development and communication and cooperation. The most emphasized teaching competency is teacher's attitude towards a student. These views were grouped under the theme of teacher's attitude towards students.

Under the sub-theme of teacher's attitude towards a student, teacher candidates say that a teacher must care students, believes all students are capable of learning and must be role model. The majority of the participants state that a teacher must believe all students are capable of learning and adopt an attitude towards students accordingly. Likewise, teacher candidates expressed their views basing on negative experiences they went through with their teacher. Dilan points out that teacher must adopt an attitude towards students by viewing students' individual differences and believe all students are capable of learning. She shares her perception of competency as follows:

"As you know, every child is unique. So, some would be slow learner by their skills. Each child has different minds and it must be considered in teaching, because we witnessed that before. They were humiliating and beating or they make ewwww. They used to make discrimination like you are hardworking and you are lazy. In my days, lazy students were sitting at the back, whereas hardworking students were sitting in the front the classroom. I was hit hard in those days. I even was alienated from the lesson."

Havva also expressed her views on all students are capable of learning and accordingly shared her primary school experiences. She said her primary school teacher only took care of 20 hardworking students in the class. She ignored other remaining 10 students and even though she wasn't one of them, she was negatively affected and decided to be classroom teacher. During the interview, she explained her opinions on that all students are capable of learning as follow:

"But they behaved us like we were idiot. And they just took care of 20 of us. I think the remaining 10 students' knowledge lay down. They would be gifted children. I think they should take a private interest. This really disturbed me."

Under the theme of teacher's attitude to a student, participants also underlined another individual characteristic of a teacher, saying that a teacher must love and care students and be fair to students. Pointing out teachers must have human love and act fair, he recalls his troubled education life and how his teacher took care of him and showed sympathy and states as follows:

"I said human love. Let me talk about it. Let me give an example. I was taught by different teacher. I mean I changed three or four schools. As far as I remember, $l$ changed four schools, until the high school. At the high school...Then I met good teachers there as well. But none of them are bad. I can't say badly, though. But of course there were some negative things. For example, the teacher wasn't fair. I mean about hard working and lazy students. For example, I didn't work hard at all until my last year I mean until the fourth grade of the high school. I mean I was a troubled guy. I was student. I mean my parents were always called. You know they told to my father. All of them complained me. But...I met a teacher, an English Teacher. In the beginning, I argued with him. But then you know he discovered me as he says. He called my parent. He called my father. He had a talk with my father alone first. Then he called me too. We talked together. And he said you are really smart. But you use your mind for other staff and bla bla. And then he said to my father. He said beside my father that promises us you will work from now on. This is your final year already. I mean they said we want you to go a reputable university. And I promised. And I'm here. Thanks to him. For the first time in my life, a teacher cared me.".

Arzu illustrates an example from her own teacher regarding the statement that teacher must care for each student. While she was going to school in a small town, her class teacher used her own efforts and brought books to students. She was very impressed since her teacher took care of them and cared students and acted fair to students. Basing on this experience, she explains the concept of teaching competency as follows:

"Being fair. I think it is the most important one. I mean no discrimination at all. If a teacher discriminates against a student, $l$ think it makes the student feel bad. Discrimination can be materially or in terms of academic success. I mean let's say if a teacher gives much more attention to a hardworking student, it sounds wrong to me. 
I mean equal attention must be given. I mean this is the capacity of the student. Teacher should be aware of it. The same thing happens in terms of materially. A teacher should treat all the students in an equal manner. This is my opinion".

Under the theme of teacher's attitude towards a student, participants also uttered following competency implication: a teacher must be a role mode. Stating that a teacher must be a role model with such attitude and values as being honest and thoughtful, she explains the perception of teaching competency as follows: "I mean our students will take us as a role model. As they will take us as a model, we should be a good model".

Another sub-theme of personal and vocational development is presented under the theme of attitude and values. According to the findings on personal and vocational development theme, participants views that a teacher must be open to personal and vocational development, perform teaching profession willingly and with enthusiasm and pays attention to self-care.

Uttering that a teacher must be idealist, Mihriban associates "being idealist" with Feride, the main character of famous novel "Çalıkuşu" and the film character Mahmut in the "Hababam Sinifi" (Chaos Class). Mihriban shares her views on being idealist as follows: a teacher must be determined to cope with difficulties, makes ceaselessly research and improve herself/himself as these characters mentioned above did. In this respect, Mihriban reflects her opinions as follows:

"I mean when I am saying being idealist, teacher must fulfil the requirements of her/his profession. The teacher should educate children in all spheres of life. The teacher must improve herself/himself. They should go beyond their higher education until they retire. In addition to that, a teacher must not just follow the courses in curriculum; he /she share information on every sphere of life as well and educate children. I mean the first thing must be education not just instruction. It is like that"

Defining performing teaching profession willingly and with enthusiasm as a teaching competency, Büşra expresses her opinions as follows: "Loving I mean loving children, loving your job. First, you cannot perform your profession without loving it. You need to love something I mean you must interest in something, so that you can develop yourself in this sense". On the other hand, Mehmet points out that a teacher must pay attention to personal care and says "Teacher must be definitely tidy. Everything must be in apple-pie order. The physical appearance of teacher is quite important. I mean when we look. I mean hair should not present a ragged, unkept. Clothing must be clean and neat."

The last sub-theme under the theme of attitude and values is Communication and cooperation sub-theme. The findings on this sub-theme mostly focus on the communication of teacher with students rather than colleagues and parents. To illustrate, Zeynep tells that she is a silent and shy student and expresses her views on the most significant competency of a teacher as follows: " $a$ teacher must make eye contact and communicate effectively." Emre associates the expression of teaching competency with effective communication skills and reflects following opinions: "Eloquence. It is like that. You should draw your students' attention. High or low voice a teacher must control them. Speaking in normal pace does not work anyway."

In terms of the teaching competency, the participants also emphasized that a teacher should empathize and tolerate in human relations. Metehan handles the issue of teaching competencies as good and bad teacher. He shares his memories with teachers and states that showing empathy is the most crucial teaching competency. Metehan explain his views as follows:

"For me, a good teacher must show tolerance. I mean a teacher need to understand students, shows empathy...For example, bad teachers I mean, bad teachers, from my point of view, they don't show empathy too much. You know it's like that for me. I mean if the teacher can show empathy, he /she can show tolerance to that person too."

Under the main theme of the perception of teaching competency, the final theme is vocation skill theme. Accordingly, designing learning environments and managing teaching and learning process sub-themes are presented. Designing learning environments were determined in accordance with the students' views on that, a teacher must pay attention to the needs of students and their individual differences in designing learning environments. Reflecting their views regarding the related sub-theme, participants defines the notion that "a teacher must pay attention to the needs of students and their individual differences in designing learning environments." as a teaching competency. Metehan shares his views as follows:

"You know some students look like they are inferior than other students, but in fact, they are not. I mean their ways of understanding are different than others. I mean a teacher should understand that way of understanding, I mean a teacher should first understand that that student understand in a different way. I mean let's say Ali doesn't understand the lesson. You cannot label the student as lazy. I mean you need to adopt different approach to that student. At least a teacher should talk with the student privately and can teach the course with different way.

Under the sub-theme of managing teaching and learning process, participants delivered their opinions on two competency implications. One of the implications is that a teacher needs to consider individual differences whilst managing teaching and learning process. Defining students with special needs as the sick children and stressing that these students need to be considered in managing teaching 
and learning process, Ramazan states as follows: "The education system of a sacked child cannot be same with the regular child. Different types of teaching methods must be carried out." Another finding obtained regarding the managing teaching and learning process sub-theme indicated that a teacher must equipped with knowledge and skills needed to educate and teach student. Explaining this perception of competency as "being equipped", Dilan "When a teacher delivers lesson, a students must say I'm understanding. Equipped. Student must grasp something. After the student goes home, he/she must say like I learned this in the school. I mean student shouldn't think like this a teacher just delivered the lesson as always and this is it. I mean being equipped. When a child asks a question, the teacher must not come to the point that he/she cannot answer." This is my opinion.

\subsection{Perceptions of Teacher Candidates on Their Teaching Competencies}

Having identified the perception of teaching competency with semi-structured interviews, the participants were asked how they perceive themselves in terms of teaching competencies. After the findings gathered were analyzed, two sub-themes, namely, "teaching competencies that they feel competent "and "teaching competencies that they lack of" were determined under the theme of perceptions of teacher candidates on their teaching competencies.

Regarding the theme of teaching competencies that they feel competent, participants defines a characteristic or competency implication that they assume as a teaching competency and feel competent. Perceiving the concept of teaching competency as an individual characteristic that a teacher must embrace, the participants thinks that they embrace these individual characteristics. Given that teacher candidates define being patient, the most frequently emphasized individual characteristic, as a teaching competency, they expressed that they are very patient. For example, Metehan remarks that some students can be late, but he will behave to their students patiently. Mehmet states "I have a patient. In every circumstance, I can be patient. Arzu thinks that a teacher must love children and be patient and believes she is competent and states: "I believe that I will behave to students with affection. I mean I was very eager to study this branch, because I love children very much too. I don't bored I mean. I am pretty sure about it. I even say I wish I could intern in the first year. I mean I'm patient. Patient is the most important one in this profession. I think patient is important. I am patient."

Participants reflected their thoughts on the competency of attitude and values in relation to the perception of teaching competency. They believe they are competent in terms of teaching competencies associated with personal and vocational development and communication and cooperation. Sharing their views on their teaching perceptions towards a teacher's attitude to a student, the participants expressed that especially a teacher must care his/her student and believe all students are capable of learning and they feel competent in this sense. Metehan, one of the participants, asserts that he can care each and every student and thus adopt an attitude that support students' development. Metehan gives an example regarding a student deemed as lazy student:

"As I said just now in the class, I mean the concept of lazy student. A student who is not lazy but considered lazy I mean I try to make that student be part of life again. I mean me I do my best maybe that student cannot do anything but $l$ do my best to make the student understand. If he/she is pessimist, I try to make him/her think positive. How can I say? I mean I give my best to the end for students with psychological problems."

Mehmet argues that every student is capable of learning and he feels competent in this respect. He believes he can even teach to slow learners and he trusts himself about this issue. He associates his competency with being patient and says:

"I can teach. I mean a student does not fail in this class. How can that be? Let's say we have one student, a slow learner. We lectured on a topic but the student didn't understand. Or we learned that the student didn't learn in somehow. We assign homework to the student. I want the student to do it by himself. We want. What kind of research does he make? Can he learn? If he doesn't do these things, then we find another way. (The researcher asks: Supposing that he couldn't learn). Then, again. Or I lecture the topic again. With different ways. There will be way that he will understand. (So, you don't give up.) Absolutely.

Declaring that "I want to be one of those impossible students who make difference", Havva believes that she is competent in terms of the competency of teacher's attitude a student. Although Havva achieved a higher score at the university exam, she preferred to study classroom education by viewing that elementary education is crucial. Expressing that she is open to improve herself and look for educational projects, Havva thinks that she can make differences. She expresses that she adopts an attitude that supports students' development and says as follows:

"Teaching profession, especially, classroom teaching is a blessed profession, because it is a fundamental education and because it has been neglected. It works only via money. Or it is like a give you money so that he/she can pass the class. Particularly, I'm thinking on new projects I know that they will be rejected. But no matter what happens, even if I am dismissed from teaching or anything else happens I mean even the worst thing happens, I will not step back. And I am on the opinion that I will take care of students to the end. Even if I have to keep going my life abroad, $\imath$ don't want to abandon those students. I believe $\mathrm{l}$ will achieve the impossible to the end, because if you do not care or me or anyone else, we all lie fallow". 
Like Havva, Büşra also feels competent in terms of the competency of teacher's attitude towards a student. During the interview, she uttered she don't want to be a good teacher but the best teacher and a different teacher. She wants a different teacher because of her role model teacher who supported her development. She believes that she can support student development and reflects her opinions as follow: "my teacher really influenced me...1 want to help people, children even if a little bit. I want to leave an impression on students; permanent impression. I mean it is not like she was my teacher. Instead, she was both my teacher and friend. I want them to talk about me using those sentences: "she helped me a lot I can't forget; she is a turning point of my life. I know that I can do that".

Regarding the sub-theme of the attitude towards students, the participants mentioned they care students and a act fair. Stating that they have the required competency, Ahmet and Arzu think that treating equally to students is a very significant competency. Saying that he has the competency of being fair, Ahmet expresses his opinions as follows: "I believe. I may have some shortages but I can improve it." Arzu shares her own ideas regarding being fair to students as follows: As I said, because I saw some things before, I am sure that I will be fair. I am so sure. I trust in myself about it.

The participants reflected their views on teaching competencies with regard to personal and vocational development, stating that they feel competent to improve themselves in terms of personal and vocational development. Mihriban expresses that a teacher must develop himself/herself to promote the versatile development of children and feel competent in this regard saying as follows: "You cannot improve yourself only learning mathematic or history. So, nowadays they are children but in the future they will be individuals who will take care of us and education starts from ground. So, we need to educate children in terms of philosophy, literature and art. So, I continuously try to improve myself in my way. I try to read books on child development. I read philosophy books. I love it. I try to apply them to my life. I also attend sign language course. Maybe in the future if god wills, I am hoping to help children.

Reflecting their perception towards communication and cooperation regarding the competency of attitude and values, participants believe that they can communicate both students and parents. Trusting in their abilities to communicate with students, Havva, Mehmet, Dilan, Mihriban and Mehmet Ali were asked how they see their competencies in terms of their communication with parents and colloquies. When Havva was asked how she deal with parents under tough conditions, she said she trusts in her ability to communicate a states "To speak frankly, I feel competent about it, because I have the power to depict something in front of me. How it is described in psychology domination or imposition I don't know. I have persuasive skills. And especially if you think your child' future, 1 can do something about that. I mean I can tell the parent to me."
Mehmet believes that he can develop warm and sincere relations with students; he gives an example of homework about his relation with parents and says "They (Parents) are the most important one. I mean I can get in touch with parents to make students do everything."

Sharing their views on communication and cooperation, participants think that they have the competency of developing empathy and tolerance. To set an example, Büşra explain it as follows: "First of all empathy, the idea that I can be that person. That's why I start with empathy I mean I try to see thinks from her/his point of view. As for Havva, Havva associates her own personal traits with empathy skills and explains:

"In terms of a characteristic of a teacher, I think that I have a stance in the class. I mean I have a hard look. People from outside cannot understand me. I'm a calm person. But I'm very careful about my tone and diction. Especially when I'm talking to someone, I pay great attention not to insult people, try to understand and be constructive and develop empathy.

Participants think that they are competent in developing learning environments which is associated with vocational skills and managing learning and teaching process Participants who claim that they consider students' individual differences, interests and needs and accordingly arrange learning environments explain their views by giving examples. For instance, Havva expresses her opinions on how she is capable of designing effective learning environments and managing teaching and learning process as follow:

"Imagine that I have 30 students in the class, 20 students already understand me, and so they don't need anything special. You can only make a contribution to them. You can convey. But, I want to deal with the remaining 10 students. For me, if you are teacher, you can call your students to your home after work hours or I can come by to their home. I lose nothing in terms of my career or my pride. I can take care of that child or discover his/her skills.. Let's say...I need to first reveal that child's area of interest. How the child listens the lesson, understand, whether the child understand through playing or the child understand the lesson through playing outdoors in nature or anywhere else or whether the child want to study alone or individually. I need to explore it so that I can address the same level of student all at once. I want to pick these 10 students and send them to a private school. I mean I want to send them by their abilities".

Participants expresses regarding the competency of vocational skill that they have the ability to manage learning and teaching environment and they based their opinion on the environment which schools locate and natural, cultural and socio-economic aspects of the environment. Being aware of that they will perform their job as Classroom Education and Preschool Education under tough conditions, they will believe that they can cope with these conditions and conduct learning and teaching 
process effectively. Mihriban argues that she has this competency and shares her views as follows:

"I think that I can teach to children to create out of nothing. I mean I can create opportunities within impossibilities. I think that I can teach it to children ... You may watch the film called "Hababam Sinufi". Remember that when the school was demolished, the teacher whose name is Mahmut continued to teach students in forestry. School is everywhere in fact. Exactly like that. I mean when $l$ work in a village school, even if there is no material l or information 1 believe that $\mathrm{c}$ can do all of them by myself."

Under the main theme of teacher candidates' perceptions towards their teaching competencies, the final sub-theme is teacher candidates' teaching competencies that they feel incompetent. Regarding this sub-theme, the participants shared their views on they feel incompetent concerning which characteristics or competency implications that they attribute as competency. The participants expressed they feel incompetent in three fields, namely, vocational knowledge, vocational skill an attitude and values.

Regarding the teacher candidates' teaching competencies that they feel incompetent, participants mostly expressed they feel incomplete or incompetent in field knowledge in terms of vocational knowledge. The participants Mihriban, Büşra, Ramazan, Dilan and Mehmet Ali who just study in the first year of the university and just attend pedagogical field education emphasized that since they are incompetent in terms of their knowledge of students' improvement characteristics, they don't know how to manage their instructional process and they feel incompetent. To set an example, Mihriban reflects how she is incompetent in terms of field education knowledge concerning the competency of vocational knowledge as follows: “ I don't have an exact knowledge of child psychology. I'm thinking about how I can educate them. I hope I learn these things here. I know how I can talk to a child, but I don't know how to behave academically or a knowledgeable. I think that I can learn these".

On the other hand, Dilan remarks that she may be incompetent in teaching the content to slow learners and explains her own teaching competency perception as follows: "Because even normal children children at this age are very ewwww( difficult)...I mean it is hard to cope with I also think that It is not easy to give a special education for them". In the same vein, Ramazan feels himself incompetent in education students with special need. Mehmet Ali explains his incompetency as follows by giving example of a hearing impaired students "I mean I will attend these one of the courses about sign language. I feel a little bit inadequate about it, because I may have a student like that. I am not competent about these issues".

Participants also feel incompetent in managing teaching and learning process with respect to the theme of vocational skills. Especially underlining that they don't know how to manage a classroom, they feel incompetent about it. Emre defines his incompetency as follows: "The areas that I feel competent...I mean we are inexperienced. You know we don't know how to control the class and draw their attraction". Metehan describes himself as an emotional person and because of his emotional character; he thinks that he will have difficulty in dealing with undesired situations in the class. Metehan reflects his views as follows:

"If I do not establish authority in the class, I mean supposing that my students wouldn't listen to me because I fail to establish authority in the class. I feel bad I mean I get touchy and you know I cannot make self-sacrifice needed for the lesson."

Reflecting their opinions on the competency of attitude and values, the participants feel incompetent in communication and cooperation competencies. The participants who think they are lack of these competencies utter that they have difficulty in communicating with their environments. Zeynep is one of these participants. According to Zeynep, the most vital competency of a teacher is effective communication. Stating that she is a silent and shy person and does not easily communicate with humans, Zeynep thinks that she has a weakness about this competency and attends the courses of Department of psychological counselling and guidance. Zeynep explains this situation as follows: "I was having difficulty in communication; I'm already receiving education now. Interpersonal communication. By attending the course, I think that I overcome this problem a little bit. Zeynep thinks that she cannot defence her arguments since she is shy and not good at communicating with her colleagues. Feeling incompetent in communication skills, Mehmet Ali thinks that he can be effective in face-to-face contact, but he will have difficulty in communicating with the whole class or the environment outside.

The participants assume that they will overcome their in competencies through undergraduate education they will receive and they imagine they will graduate in a way that they are equipped with teaching competencies. Accordingly, Mehmet explains his perception towards teaching competency as "degree". Mehmet believe and trust in himself in terms of teaching competencies. As well as his prevalent competencies, he thinks that he will also complete his other in competencies by means of education. He defines "degree" as an implication of acquired teaching competency and states "The person who receives the "degree" means that the person embraces those characteristics".

Considering opinions under the theme of teacher candidates' perceptions towards their teaching competencies, first grade students feel competent in terms of the competencies under the theme of attitude and values and vocational skills. This finding is consistent with the result, indicating that the participants achieved higher 
mean scores in the scale which mostly involves items on these two competency areas.

When we analyze the scale items administrated to the participants, these items are mostly related to these two competency areas. The participants were asked how they perceive their teaching competencies on their attitude to students and designing learning environments and qualitative findings were obtained. These findings are consistent with quantitative findings which participants demonstrated higher scores with respect to the following items If I try hard enough, I know that I can positively impact on my students' personal and academic developments. I believe, in time, I will meet the needs of my students more.

The lowest score $(\bar{X}=3.40)$ was measured in the item scale "I know that I can develop new projects even though my colleagues do not agree with me. Only one of the participants said that he/she has the competency of communication and cooperation, other participants mostly associated their competency with the competency of communication with students.

The lowest second score $(\bar{X}=3.43)$ was measured in the item scale "I believe in my ability to respond students' needs even when I go through difficult times". Participants were asked to explain why they gave low score to this item by asking additional questions. Participant responded that they perceived the expression of " even I go through difficult times" as the day they lost their one of the relative or taking a bad new and for this reason they believed they would unable to meet students' needs.

Participants who have lack of some competencies are resulted from they have inadequate knowledge of pedagogy. This finding is not consistent with any findings of the scale. This is because the scale mainly consists of vocational skills and attitude and values.

\section{Discussion}

The current study attempted to examine the perceptions of first grade teacher candidates enrolled in Faculty of Education towards teaching. In this respect, the levels of teacher candidates' competencies were analyzed using a scale in the quantitative phase. As for the qualitative stage, competencies that teacher candidates need to embrace and teacher candidates' perceptions on their teaching competencies were examined. In this research, a mixed research, sequential explanatory mixed design was utilized and quantitative data first were analyzed. Basing on the findings from the qualitative data analysis, quantitative data was statistically analyzed via semi-interview method. The scale on teaching profession developed by [1] was employed for data collection in the quantitative stage of the research. According to the data obtained, it is found that the sample group generally responded as "Strongly Agree" in the 10-item scale and the mean of all items in the scale resulted in the competency level of "Strongly Agree". Correspondingly, it is found that teacher candidates have a higher level of competency perception. Various studies carried out by [20], [21], [22] indicated that teacher candidates have higher and lower competency perception levels towards their own profession. The item with the highest mean score was found to be the item number 7 "If I try hard enough, I know that I can positively impact on my students' personal and academic developments. " and the item with the lowest mean regarding teaching competency was found to be the following item number 10 "I know that I can develop new projects even though my colleagues do not agree with me."

However, the striking finding is that there is a slight difference between two items. We thus can imply that the views of teacher candidates on teaching competencies are similar to each other. In addition to that, we could argue that teacher candidates handle teaching competencies in a wholly way. In the same vein, [23] posits that knowledge, skills, attitudes and individual characteristics that are indispensable parts of effective teaching performance in different teaching environments must be described as the fundamental components of teaching competencies. From another angle, the fact that teacher candidates are aware of their teaching competencies means that they will have the opportunity to effectively apply their gains from teaching to their students. Similarly, [21] argues that teaching competency levels immensely impacts students' learning process and the higher competency level of a teacher means more permanent learning experience for students. The survey carried out by the Organisation for Economic Co-operation and Development (OECD) in 2003 revealed that teachers' attitudes, behaviours and interactions with their students, in other words, teaching competencies, directly influence learning process.

An in-depth analysis on teaching competencies was carried out so that direct effects of teaching competencies on both teachers and students were observed. Basing on the quantitative data, it was attempted to develop different perspectives. Following the quantitative analysis, semi-structured interview was conducted with teacher candidates and as a result, two main themes were identified, namely, the perception of teaching competency and the perceptions of teacher candidates on their teaching competencies. The main theme of the perception of teaching competency was divided into following sub-themes: attitudes and values, and vocational skills. The participants described teachers as "patient, compassionate, self-sacrificing, kindly but firmly or authoritative". It is thus inferred that teacher candidates misconceptualize the concept of competency. By expressing teachers' individual characteristics, the participants remarked that teachers had a significant influence on students' learning process. [7], [8] argue that "the effectiveness of a competency-based curriculum depends on covering up all developments in every sphere of a society, guiding students, 
motivating them to learn, active student participation and undertaking responsibility by the student. This means that no matter how a curriculum is effectively prepared, teachers should be aware of their own competencies and improve themselves to a certain degree and therefore will be able to have an efficient and qualified teacher profile.

"Being Patient" is the most stressed individual characteristics by the participants. Teacher candidates perceive "being patient" as a teaching competency and they expressed that they are very patient. Regarding the theme of teaching competencies that they feel competent, participants defines a characteristic or competency implication that they assume as a teaching competency and feel competent. Given that [24] also stresses that a not only a teachers' knowledge, skill and attitudes impact on students, but also their behaviours while instruction have a great influence on students and he argues that a patient teacher showing sympathy positively influences students, whereas opposite behaviours of teachers pose negative results on students. In the same vein, [28] asserts that a good teacher must have interpersonal skills, be flex, patient, tidy, trustworthy. This means that both research findings and other researchers' opinions meet on a common ground.

Under the main theme of teacher candidates' perceptions towards their teaching competencies, the final sub-theme is teacher candidates' teaching competencies that they feel incompetent. The participants expressed they feel incompetent in three fields, namely, vocational knowledge, vocational skill an attitude and values. Regarding the teacher candidates' teaching competencies that they feel incompetent, participants mostly expressed they feel incomplete or incompetent in field knowledge in terms of vocational knowledge. Given that the concept of competency has been defined as follows: "being equipped with the needed knowledge, skill and attitude to execute job duties [25]; "the achievement of job duties in an effective and efficient manner by the employee" and "acquiring the needed knowledge and skills to exhibit an attitude [26], we can infer that such definitions are consistent with the research findings in that the majority of the teacher candidates emphasizes the area which they want to feel themselves competent is field area. Given that [27] carried out a research on teacher candidates' field knowledge and concluded a teacher lacking field knowledge would not efficiently perform his/her profession, this outcome supports the research finding.

\section{Conclusion and Implications}

The present study aimed to identify the perceptions of first grade teacher candidates enrolled in Faculty of Education towards teaching profession and whether they have teaching competencies needed or not. In this respect, it is found that teacher candidates associate the concept of teaching competency with individual characteristics. Recent studies also confirm the importance of individual characteristics in teaching profession. There, we could recommend that different types of tests can be administrated to students to identify their individual characteristics when accepting students to education faculties.

In addition to that, given that teachers must be competent in vocational attitude and skills such as teacher's attitude towards a student and designing learning environments , curriculum courses in education faculties should be effectively developed to allow students gain these attitude and skills. In this sense, appropriate learning environments should also be created so that teacher candidates can be able to practice these attitude and skills before they graduate. The objective of the current study is to identify of first grade teacher candidates' vocational awareness. Future researches could be conducted with the participation of teacher candidates on different grade levels. Furthermore, longitudinal study can be administered to the same sample group, thereby analyzing changes in vocational qualification awareness. Teacher candidates can also be encouraged to meet real learning environments where they will have the opportunity to explore themselves, aware their competencies and to increase their awareness on whether they could perform.

\section{REFERENCES}

[1] Schwarzer, R. (Ed.) (1992). Self-efficacy: Thought control of action. Washington, DC: Hemisphere.

[2] Sünbül, A.M. \& Arslan, C. (2007). Öğretmen Yeterlik Ölçeğinin Geliştirilmesi Üzerine Bir Araştırma [A Research on the Development of the Teacher Proficiency Scale]. Eskişehir Osmangazi University Journal of Social Sciences Institute, 7 (2).

[3] Süral, S. (2016). Öğretmenliğin Rolü ve Özellikleri [The Role and Features of Teacher]. (Ed. Fatma Susar Kırmızı ve Nil BUDAN). Eğitim Bilimine Giriş. Anı Yayıncılık. Ankara.

[4] Şişman, M. (2006). Eğitim Bilimine Girişs [Introduction to Educational Science], Ankara: Pegem A Yayınc1lık.

[5] Süral, S. (2013). İlköğretimde Görev Yapan Öğretmenlerin Öğretme Stillerinin Sinıf Yönetimi Yaklaşımları Ve Öğretmenlik Mesleğine Yönelik Tutumları Arasındaki İlişki [The Relationship Between Classroom Management Approaches and Teachers 'Attitudes Towards Elementary Teaching Teachers' Teaching Styles] yayımlanmamış doktora tezi, Adnan Menderes Üniversitesi Sosyal Bilimler Enstitüsü, Aydın.

[6] Akyüz, Y. (2003). Osmanlıdan Günümüze Öğretmen İstihdam Illke ve Politiklarına Eleştirel Bir Bakış [A Critical Look at the Principle and Policy of Employment of Teachers in the Ottoman Empire]. Öğretmen Yetiştirme ve İstihdamı Sempozyumu. 165-188.

[7] Abbott, J. \& Ryan, T. (1999). Constructing knowledge, reconstructing schooling. Educational Leadership, 57(3), 
66-69.

[8] Holloway J. H. (1999). Caution: constructivism ahead, Educational Leadership, 57 (3), 85-86. Princeton.

[9] Brooks G. \& Books M G. (1999). The Courage ta be Constructivist. Educational Leadership.

[10] Erdem, E. (2001). Program Geliştirmede Yapılandırmacılık Yaklaşımı [Constructivism Approach on Curricullum İnstruction]. (Yayınlanmamış Yüksek Lisans tezi) Hacettepe Üniversitesi Sosyal Bilimler Enstitüsü, Ankara.

[11] Yaşar, Ş. (1998). Yapısalcı Kuram ve Öğrenme-öğretme Süreci [Constructivist Theory and Learning-teaching Process]. National Educational Science Congress Selçuk Üniversitesi. Konya.

[12] Alkove, L. D. \& B. J. McCarty. (1992). Plain talk: recognizing positivism and constructivism in practice. Action in Teacher Education. 14 (2) 16-22.

[13] Creswell, J.W. \& Plano Clark, V.L. (2014). Designing and Conducting Mixed Methods Research. (Çev. Yüksel DEDE, Selçuk Beşir DEMİR). Anı Yayıncılık. Ankara.

[14] Gall, J.; Gall, M.D.; Borg, WR. (1999). Appling educational research. New York: Longman.

[15] Büyüköztürk, Ş. (2006). Sosyal bilimler için veri analizi el kitabı [Manual of Data Analysis for Social Sciences]. Ankara: Pegem A Yayıncılık.

[16] Tezbaşaran, A. (1996). Likert Tipi Ölçek Geliştirme Kilavuzu [Likert Type Scale Development Guide]. Turkish Psychological Association Publications. Ankara.

[17] Ekiz, D. (2015). Bilimsel Araştırma Yöntemleri [Scientific Research Methods] (4.Bask1). Anı Yayıncılık, Ankara.

[18] Yıldırım, A. \& Şimşek, H. (2013). Sosyal bilimlerde nitel araştırma yöntemleri [Qualitative research methods in the social sciences]. (9.Baskı). Ankara: Seçkin Yayıncılık.

[19] Braun, V. and Clarke, V. (2006). Using thematic analysis in psychology. Qualitative Research in Psychology, 3 (2), 77-101.

[20] Erişen, Y., \& Çeliköz, N. (2003). Öğretmen adaylarının genel öğretmenlik davranışları açısından kendilerine yönelik yeterlilik algıları [Teacher candidates' perceptions of their proficiency in terms of general teaching behaviors]. The Journal of Turkish Educational Sciences, 1(4), 427-439.

[21] Karacaoğlu, Ö. C. (2008). Öğretmenlerin yeterlilik algıları. Yüzüncü Yıl Üniversitesi Ĕgitim Fakültesi Dergisi, 5(1).

[22] Çapri, B. \& Çelikaleli, Ö. (2008). Öğretmen adaylarının ögrretmenliğe ilişkin tutum ve mesleki yeterlik inançlarının cinsiyet, program ve fakültelerine göre incelenmesi [Examination of teacher candidates' attitudes towards teaching and profession competence beliefs according to gender, program and faculties]. Inonu University Journal of Faculty of Educational, 9 (15).

[23] Çetinkaya, Z. (2009). Türkçe Öğretmen Adaylarının Öğretmenlik Mesleğine İlişkin Tutumlarının Belirlenmesi [Determination of Turkish Teacher Candidates' Attitudes towards Teaching Profession]. İlköğretim Online, 2 (8), 298- 305.

[24] Güçlü, N. (2000). Teacher Behaviors, The Journal of National Education, 147, 21-23.

[25] MEB, (2008). Öğretmen Yeterlikleri: Öğretmenlik Mesleği Genel Ve Özel Alan Yeterlikleri [Teacher Proficiency: General and Special Field Qualifications of Teacher Profession]. Devlet Kitapları Müdürlüğü, Ankara.

[26] Üstüner, M., Demirtaş H., Cömert M., Özer N. (2009). Ortaöğretim öğretmenlerinin özyeterlik algıları [Self-efficacy perceptions of secondary school teachers]. Mehmet Akif Ersoy University The Journal of Faculty of Education, 9(17), 1- 16.

[27] Veal, W. R., Tippins, D. J. ve Jefferson, J. B. (1999). The Evolution of Pedagogical Content Knowledge in Prospective Secondary Physics Teachers.

[28] Aslan, M. (2011). Öğretmen Liderliği Davranışları ve Sınıf Iklimi: Ögretmen ve Ögrenci Görüşleri Bağlamında Bir Araştırma [Teacher Leadership Behaviors and Class Climate: A Research in the Context of Teacher and Student Opinions]. Yüksek Lisans Tezi. Eskişehir: Eskişehir Osmangazi Üniversitesi. 